\title{
Effectiveness of Antelope Pass Structures in Restriction of Livestock
}

\author{
BRYAN D. GROSS, JERRY L. HOLECHEK, DENNIS HALLFORD, AND REX D. PIEPER
}

\begin{abstract}
A study was conducted to test the restrictive efficiency of 5 antelope pass structures upon cattle and sheep. Cattle and sheep were placed under 3 stress situations, female water, female young, and male-female, to test fence restrictive ability of individual antelope pass structures. No single structure restricted all classes and types of livestock. Depending upon livestock class and type, proper selection and use of antelope pass structure will restrict livestock movement without severely restricting antelope movement. An 81.3-cm ( 32 in) net-wire fence most effectively restricted sheep, but cattle were most effectively restricted by a $2.4-\mathrm{m} \times 1.5-\mathrm{m}(8 \mathrm{ft} \times 5$ ft) horizontal grill. It appears that a horizontal grill within a fence line with certain modifications and placement constraints will effectively restrict sheep and cattle but permit antelope passage.
\end{abstract}

Fencing has been a standard livestock management practice since cattle and sheep were first introduced on western ranges. The use of fences to divide rangelands into manageable areas can achieve important livestock management objectives. May (1968) summarized a number of key advantages of fencing western ranges. These include more uniform distribution of animals, protection of overgrazed or treated areas, segregation of livestock classes or types, increased forage production and reduction in handling of livestock. Certain fence designs, however, have the important disadvantagc of restricting movement of some wild ungulate species.

Wild life managers recognize fencing as a major management problem associated with the pronghorn antelope. Certain fences can restrict pronghorn movements to obtain food and/or water, or to escape harsh weather (Yoakum 1978, 1980). Russell (1951) included net-wire fences as an important factor contributing to reductions in pronghorn numbers throughout the West. Newman (1966) found that Wyoming antelope numbers decreased substantially when animals were restricted by livestock fences. Antelope that were not allowed free movement over a large area were in poor condition and showed signs of starvation. Other studies noted similar results (Mapston 1972, Russell 1951).

A variety of structures are presently employed on western ranges depending upon the operation, livestock type, and class. Sheep operators prefer net-wire fencing; operations involving cattle may require use of barbed wire for restrictive purposes. Mapston (1972) suggested that both net-wirc and certain barbed wire fences can cause serious problems for antelope by restricting both movement and feed selection.

Bear (1969) found that sheep fences, $1.1 \mathrm{~m}$ (44 in) in height will restrict nearly all antelope, while net-wire structures $81.3 \mathrm{~cm}$ (32 in) high will restrict only fawns. On cattle ranges where barbed-wire fences are common, antelope were less restricted but often injured during passage, which resulted in permanent crippling or death (Spillett 1965). In all cases it appears that standard livestock fences

\footnotetext{
Authors are graduate research assistant, assistant professor, associate professor, and professor, Department of Animal and Range Sciences, New Mexico State Uni versity, Las Cruces 88003.

This report is Journal Article 836, Agricultural Experiment Station, New Mexico State University. Las Cruces. Funding for this research was provided by the Bureau of Land Management.

Manuscript received April 27, 1981.
}

have some negative effect upon antelope.

After reviewing several studies Yoakum $(1978,1980)$ suggested measures to be taken to reduce mortality from fencing. These included minimizing construction of net-wire fences, using barbed wire fences with a smooth bottom strand at least $41 \mathrm{~cm}$ (16 in) above the ground and no stays between posts, providing special pass structures such as lay-down panels or antelope jumps along heavily traveled pathways and/or migration routes, and maintaining large areas.

The development of a structure to solve the antelope/fence problem has become an important research objective but no definite answer has been found. Spillett et al. (1967) concluded from field observations and experiments that maximum height for any vertical structure intended for antelope passage should be no greater than $81.3 \mathrm{~cm}$ ( $32 \mathrm{in}$ ). Kerr (1968) documented frequent use of $81.3-\mathrm{cm}$ passes in net-wire fences and areas where woven-wire was replaced by barbed wire. Spillett et al. (1967) recommended that where vertical structures are required for livestock restriction only smooth wire be used to reduce injuries to antelope.

Several st udies have shown antelope passage is more frequent on horizontal modified cattleguards (Bear 1969, Spillett 1965, Pate 1969, Mapston 1970). Observations of antelope utilizing cattleguards as a means of passage are numerous (Mapston et al. 1970, Spillett and Zobell 1967, Pate 1969, Spillett 1965, Zobell 1968a, $1968 \mathrm{~b}$ ). These observations indicate that antelope commonly leap $1.8-\mathrm{m}$ and $2.1-\mathrm{m}(6$ and $7 \mathrm{ft})$ cattleguards when the width of the structure is no less than $1.8 \mathrm{~m}(6 \mathrm{ft})$. Mapston (1968) and Pate (1969) found that these horizontal devices worked effectively even to the extent of allowing passage of 1-month-old fawns. Studies by Bear (1969), Newman (1966), and Mapston (1968) have verified movement of antelope in and out of pastures with net-wire perimetcr fences when experimental horizontal passes were present. These studies indicated that problems associated with antelope restriction by livestock fences can be solved by use of low vertical passes or, preferably, horizontal cattleguard devices.

Since research and observation have shown that antelope can negotiate passage, the effectiveness of such pass structures in restricting livestock movement becomes a concern. A limited number of studies have dealt with this matter (Cole 1956, Spillett et al. $1967)$ but results were not conclusive. Bear (1969) found that, although several vertical structures adequately restricted livestock, these structures were different than recommended for antelope passage. Mapston et al. (1970) concluded that a $1.8-\mathrm{m}(6 \mathrm{ft})$ horizontal grill would serve to restrict most livestock movement without restricting antelope. Sheep were not always effectively restricted by any structure, however. The problem of developing structures which will restrict livestock, but not antelope, needs further investigation. The objective of this study was to test the restrictive efficiency of 5 antelope passes on sheep and cattle.

\section{Materials and Methods}

Four vertical panel structures (Fig. 1) and one horizontal grill (Fig. 2) were selected for tests involving livestock. An 81.3-cm (32 in) vertical net-wire fence was used as a control. This structure is commonly used as a standard livestock fence for sheep. Two 
4 strand barbed wire standard (A)

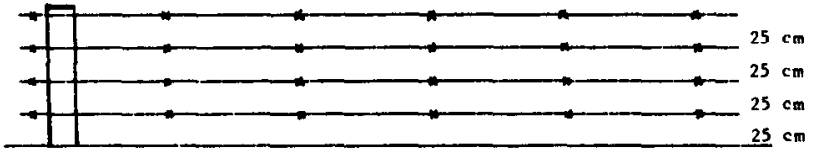

4 strand barbed wire variation (B)

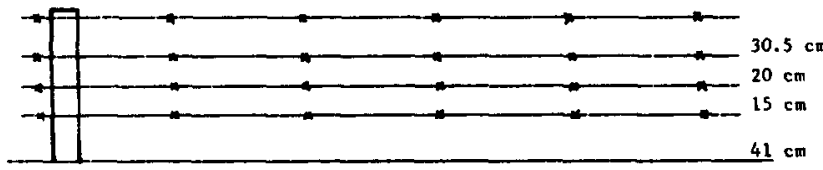

81.3 centimeter net-wire (C)

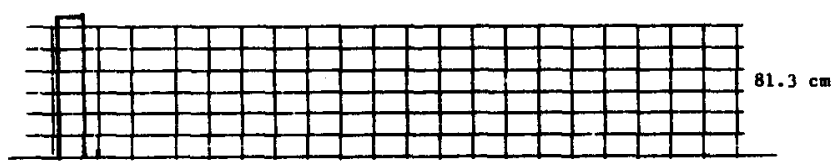

Net-wire vartation (D)

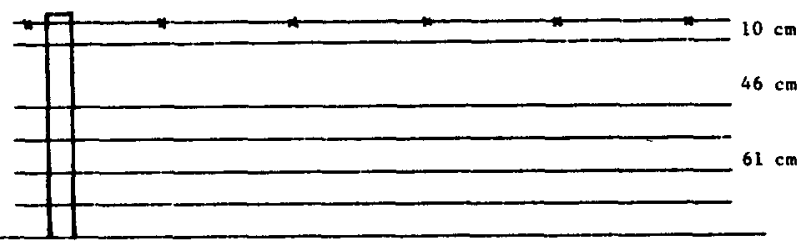

Fig. 1. Characteristics of experimental antelope passes.

barbed wire fences were tested, both consisting of 4 barbed wire strands. The first barbed wire panel (Fig. 1a) has been used by government agencies and ranchers for restriction of cattle. This structure consisted of 4 wire strands spaced equally at $25.4-\mathrm{cm}$ (10 in) intervals from ground level. A second barbed wire structure (Fig. 1b.) is termed a barbed wire variation. This consisted of 4 strands separated by distances of $41 \mathrm{~cm}(16 \mathrm{in}), 15 \mathrm{~cm}(6 \mathrm{in}), 20 \mathrm{~cm}$ ( 8 in), and $31 \mathrm{~cm}(12 \mathrm{in})$, beginning at ground level. Total vertical heights of the 2 barbed wire structures were $1 \mathrm{~m}$ (40 in), and $1.1 \mathrm{~m}$ (42 in), respectively. A fourth panel (Fig. 1d) used net-wire in conjunction with one barbed wire strand. The net-wire portion consisted of four smooth wire strands supported by equally spaced wire stays. Wire strands were placed at $15 . \mathrm{cm}(6$ in) intervals, extending to a vertical height of $61 \mathrm{~cm}$ (24 in). Forty-six cm (19 in)

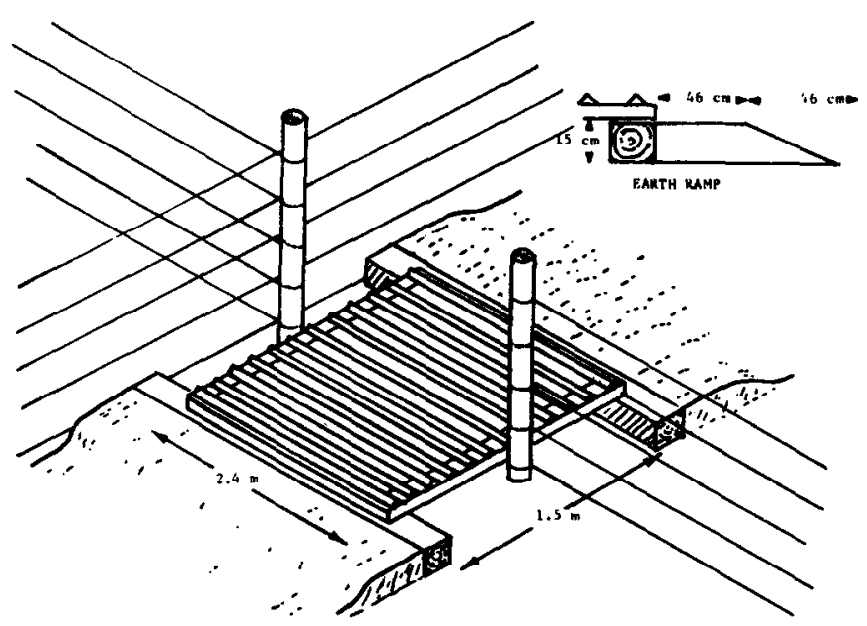

Fig. 2. Characteristics of the horizontal antelope grill. (Adapated from Mapston and Zobell, 1970. above the net-wire portion a fifth smooth wire strand was placed. The uppermost strand was barbed and was placed $20 \mathrm{~cm}(8 \mathrm{in})$ above the upper smooth wire strand for a total vertical height of 1.2 $m$ (46 in). A final antelope pass structure was the horizontal antelope grill by Mapston et al. (1970) (Fig. 2). Construction of vertical test panels was identical in all test situations except for those in which the cow was separated from calf. Those tests will be discussed later.

For test purposes an enclosure having a total length of $49 \mathrm{~m}(160$

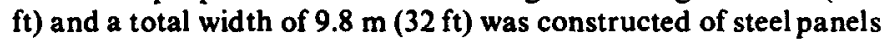
(Fig. 3). Five individual test paddocks, equal in size, were constructed within the enclosure. This allowed for the simultaneous conducting of 5 independent trials. Each test paddock was equally sectioned into 2 subunits. These subunits were separated by individual test panels. The total length of a test panel within each test paddock was $9.8 \mathrm{~m}$ ( $32 \mathrm{ft})$. A 7-foot steel support post was placed at the midpoint of each test panel. The structure of the enclosure allowed tests to be conducted independently and animals under stress to have maximum exposure to each test panel.

Tests of all panels were conducted using 2 livestock types, cattle and sheep. Two breeds of cattle, Hereford and crossbred Brangus, were used although no differentiation was made when recording results. Breeds of sheep used were Rambouillet and Suffolk. Again no differentiation was made in breed response.

Three stress situations were applied to both cattle and sheep. These situations included male/female stress, female/water stress, and female/ unweaned young stress. These three stress situations, are present in range livestock operations, and were therefore necessary for evaluations of test panels. Lambs used in the ewe/lamb trials ranged from 4 to 7 weeks of age, while calves used in the cow/calf trial were approximately 12 weeks of age.

All tests involved construction of test panels between paddock subunits with placement of animals opposite specific stress factors. The cow/calf tests involved placement of an additional strand of

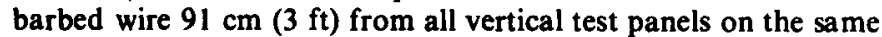
side of the test panel as the cow. This prevented calves from nursing through the test panel. Horizontal antelope grills were placed at one end of each test paddock between subunits. This simulated recommended placement of these structures on pasture corners in range situations.

Male-female trials involved the use of chemical stimulators to syncronize estrus in females. Cow estrus synchronization involved regular injections of lutalyse (dinoprost tromethamine) while ewe estrus syncronization involved regular injections of estrogen and progesterone.

For each pass structure the stress situation for each animal type was replicated 10 times. Each test involved an exposure period of 24 hours with an additional 24-hour stress period for female/water trials. The standard chi-square was used for all statistical testing (Steel and Torrie 1960). All data are expressed as percentages of animals which crossed each type of restriction.
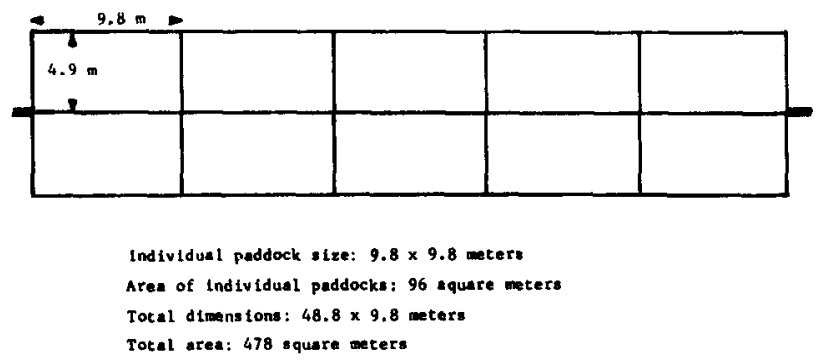

Fis. 3. Characteristics of the experimental area. Individual paddock size: $9.8 \times 9.8$ meters Area of individual paddock: 96 square meters Experimental area size: $48.8 \times 9.8$ meters Area of experimental unit: 478 square meters 
Table 1. Values represent the percent of animals crossing each panel type. $V$ alues with different superscripts within a row were significantly different $(P<.05)$ in restrictive efficiency.

\begin{tabular}{lccccc}
\hline \hline Category & $\begin{array}{c}\text { 4-strand } \\
\text { barbed } \\
\text { wire }\end{array}$ & $\begin{array}{c}\text { Barbed } \\
\text { wire } \\
\text { variation }\end{array}$ & $\begin{array}{c}81.3-\mathrm{cm} \\
\text { net- } \\
\text { wire }\end{array}$ & $\begin{array}{c}\text { Net } \\
\text { wire } \\
\text { variation }\end{array}$ & $\begin{array}{c}\text { Antelope } \\
\text { grill }\end{array}$ \\
\hline 1 cattle & $43.3^{\mathrm{b}}$ & 30.0 & 53.3 & 56.7 & 26.7 \\
2 sheep & $60.0^{\mathrm{b}}$ & $70.0^{\mathrm{b}}$ & $30.0^{\mathrm{a}}$ & $70.0^{\mathrm{b}}$ & $70.0^{\mathrm{b}}$ \\
3 adult cattle & $40.0^{\mathrm{a}, \mathrm{b}}$ & $35.0^{\mathrm{a}}$ & $80.0^{\mathrm{c}}$ & $70.0^{\mathrm{b}, \mathrm{c}}$ & $15.0^{\mathrm{a}}$ \\
4 adult sheep & 40.0 & 55.0 & 45.0 & 65.0 & 65.0 \\
5 calves & 50.0 & 20.0 & 00.0 & 30.0 & 50.0 \\
6 lambs & $100.0^{\mathrm{b}}$ & $100.0^{\mathrm{b}}$ & $00.0^{\mathrm{a}}$ & $80.0^{\mathrm{b}}$ & $80.0^{\mathrm{b}}$ \\
7 adults & $40.0^{\mathrm{a}}$ & $45.0^{\mathrm{a}, \mathrm{b}}$ & $62.5^{\mathrm{b}, \mathrm{c}}$ & $67.5^{\mathrm{c}}$ & $40.0^{\mathrm{a}}$ \\
8 young & $75.0^{\mathrm{b}}$ & $60.0^{\mathrm{b}}$ & $00.0^{\mathrm{a}}$ & $55.0^{\mathrm{b}}$ & $65.0^{\mathrm{b}}$ \\
9 total & 51.7 & 50.0 & 41.7 & 63.3 & 48.3 \\
\hline
\end{tabular}

\section{Results}

There were no significant differences $(P>.05)$ between any antelope passes when results were summed over all livestock classes and types (Table 1). Two individual categories, cattle and sheep, showed no significant differences $(P>.05$ ) occurred among the panels for cattle, but differences were significant for sheep. The $81.3-\mathrm{cm}$ ( $32 \mathrm{in}$ ) net-wire control panel was superior to other passes for sheep restriction. Results from adult cattle trials show that the horizontal antelope grill was significantly better $(R<.05)$ than the $81.3-\mathrm{cm}(32 \mathrm{in}) \mathrm{net}-$ wire control and the net-wire variation. The $81.3-\mathrm{cm}(32 \mathrm{in})$ net-wire control was significantly better $(P<.05)$ than all other panels in the lamb/ewe trials as indicated by the lamb category. Both the 81.3-cm net-wire control and the net-wire variation were inferior to the horizontal antelope grill and the 4 strand barbed wire standard in the restriction of adults. Young animals were completely restrained by the $81.3-\mathrm{cm}$ net-wire control.

\section{Discussion}

Analysis of data indicates that no single panel structure ultimately solved the problem of livestock restriction. Passes that proved successful in restricting cattle movement were those constructed of barbed wire. Where smooth wire was included cattle were able to press against the fence and push down the panel. The $81.3-\mathrm{cm}$ ( $32 \mathrm{in}$ ) net-wire fence did not restrain cattle because of its height. Cattle stepped over the structure or pushed it down. This was also true for the net-wire variation even though it did contain one barbed wire strand.

Sheep and calves were able to crawl through several fence types. All wire strand fences were inferior to the $81.3-\mathrm{cm}$ ( 32 in) net-wire control panel when the trial involved smaller livestock. Barbed wire strands had little effect on discouraging these animals from crossing. Lambs in particular were able to pass beneath wire strands on all fences except the $81.3-\mathrm{cm}$ net-wire control.

Although sheep and calves did not jump over fence structures, as did adult cattle, they were capable of jumping the horizontal grill. Typically, crossings were accomplished by an angular jump of approximately $76 \mathrm{~cm}$ from the guard corner where the fence intercepts the panel into the adjacent paddock subunit. This problem could be partially solved by the addition of wings to each end of the antelope gua rd. Crossings of the horizontal grill by lambs were also made by walking down a center steel support strip approximately $15.2 \mathrm{~cm}$ (6 in) in width. The removal or narrowing of this support may alleviate this problem.

The ability of different animal classes and animal types to cross panel structures complicates development of an effective antelope pass which will restrain livestock but allow passage of antelope. The ability of cattle to jump low fences and break through smooth strand fences coupled with the ability of sheep to jump or crawl through these structures increases design problems. Pass structures that will restrict both cattle and sheep may have a similar effect upon antelope

In all study situations, stress factors as well as exposure to antelope panels was much greater than would be expected in range situations. This would have the effect of increasing the percentage of livestock crossing in all tests. Selection of a pass structure depends upon type and class of livestock utilizing an area. Where cattle are the primary livestock type, results indicate that the horizontal grill or the 4-strand barbed wire standard could be effectively used. Although both pass types may serve to restrict cattle, observations indicate that the horizontal grill is more readily utilized by antelope (Kerr 1968). The horizontal grill may serve to restrict cattle effectively without inhibiting antelope passage. The horizontal grill is recommended for all pastures where adult cattle are located, including areas used for breeding purposes. Calving pastures may require use of the $81.3-\mathrm{cm}$ ( $32 \mathrm{in}$ ) net-wire fence or the modified horizontal grill. The 4-st rand barbed wire standard or the net-wire variation will also restrict calf movement.

The modified horizontal grill is recommended (for adult sheep). Lambing pastures may require use of the $81.3 \mathrm{~cm}$ net-wire fence of the modified horizontal grill.

Selection of the area to place an antelope pass is extremely important. Pasture use, shape, size, and topography should be considered. Topographical features play an important role in patterns of livestock use, and thus, is important in decreasing livestock exposure to the pass as well as increasing antelope exposure. Placement of passes upon ridgetops will generally be more beneficial to antelope than placement of the structure in low areas. This will also decrease livestock exposure to the pass. Structures should be placed in pasture corners or areas away from areas frequented by livestock. Placement in these areas will also funnel antelope into these areas and thus increase antelope exposure. Placement of passes away from water sources, salting areas, livestock trails, and vehicle routes can further reduce livestock exposure to these structures.

\section{Literature Cited}

Bear, George D. 1969. Antelope and net wire fences. Proc. West. Ass. State Game and Fish Comm. 49:265-271.

Cole, G.F. 1956. The pronghorn antelope-its range use and food habits in central Montana with special reference to alfalfa. Montana Agr. Exp. Sta. Tech. Bull. 516.

Kerr, R.M. 1968. A discussion of the woven-wire fence antelope situation on BLM lands in New Mexico. Proc. of the 3rd Biennial Antelope State Workshop: 22-27.

Mapston, R.D. 1968. The use of structures to facilitate antelope movement through sheep-tight fences. M.S. Thesis, Univ. Arizona, Tucson. 79 p.

Mapston, R.D. 1970. Casper antelope pass studies. Proc. of the fourth biennial states workshop. 116-124.

Mapston, R.D. 1972. Guidelines for fencing on antelope ranges. Proc. Biennial Antelope States Workshop 5:167-170.

Mapston, R.D., R.S. Zobell, Kenneth B. Winter, William D. Dooley. 1970. A pass for antelope in sheep-tight fences. J. Range Manage. 23:457-459.

May, Morton. 1968. Fencing for livestock management. Proc. Biennial Antelope States Workshop. 3:62-64.

Newman, Johr L. 1966. Effects of woven wire fence with cattleguards on a free-living antelope population. Proc. Antelope States Workshop. 2:6-8.

Pate, L. 1969. Antelope populations studies-completion report. Work Plan 10, Job 4, Wyoming G. and F. Comm., Fed. and Project. 17-19. Russell, P.T. 1951. Crisis of antelope management. Wyoming Wild. 15:4-9.

Spillett, J.J. 1965. Effects of livestock fencing on pronghom antelope movements. M.S. Thesis, Utah State University, Logan.

Spillett, J.J., J.B. Low, and D. Sill. 1967. Livestock fences-how they influence pronghorn antelope movements. Utah State Univ. Agr. Exp. Sta. Bull. 470.

Spillett, J.J. and R.S. Zobell. 1967. Innovations in trapping and handling pronghorn antelopes. J. of Wildl. Mgt. 131:347-351.

Steel, Robert G.D., and J.H. Torrie. 1960. Principles and procedures of statistics. McGraw-Hill Book Co., Inc., N.Y.

Yoakum, James D. 1978. Pronghorn. p. 103-123. In: Big Game of North America. Stackpole Books, Harrisburg, $\mathrm{Pa}$.

Yoakum, J. 1980. Habitat management guides for the American pronghorn antelope USDI-BLM, Denver Service Center Tech. Note 347.

Zobell, R.S. 1968a. Field studies of antelope movements on fenced ranges. Trans. N. Amer. Wildl. and Nat. Res. Conf. 33:211-216.

Zobell, R.S. 1968b. A review of antelope crossing devices: Field trials of antelope passes in Buffalo Basin. Proc. Biennial States Workshop. 3:2830 . 